International Journal of Social Science (IJSS)

Vol.1 No.2 August 2021, pp: $43-48$

ISSN: 2798-3463 (Printed) | 2798-4079 (Online)

DOI: https://doi.org/10.53625/ijss.v1i2.135

\title{
THE QUALITY OF E-KTP SERVICE IN CIBEUNYING KALER SUBDISTRICT AT BANDUNG MUNICIPALITY INDONESIA
}

\author{
By \\ Sunasih Mulianingsih ${ }^{1}$, Engkus ${ }^{2}$, Tika Ayu Tri Lestari ${ }^{3}$ \\ ${ }^{1}$ Institut Pemerintahan Dalam Negeri Sumedang - Indonesia \\ ${ }^{2,3}$ UIN Sunan Gunung Djati Bandung - Indonesia \\ E-mail: ${ }^{1}$ sunasihmulianingsih@gmail.com, ${ }^{2}$ engkus@uinsgd.ac.id, ${ }^{3}$ tikaayutrilestari@gmail.com
}

\begin{tabular}{l}
\hline Article Info \\
\hline Article history: \\
Received May 12, 2021 \\
Revised June 21, 2021 \\
Accepted July 21, 2021
\end{tabular}

Keywords:

Service Quality

Optimization

E-KTP

\begin{abstract}
The quality of E-KTP service is one of the basic forms of government services to the community. The main problem of this research is that the quality of EKTP service at the Cibeunying District Office, Bandung City is not optimal and not satisfactory. Optimizing e-KTP services is needed to improve service quality and satisfy the community. This synthesis is the subject of this article. The research method used is a qualitative approach with data collection techniques: observation, interviews and literature study. Based on the research results, the service is not optimal because it is not fully based on the dimensions: 1. Service Speed, 2. Cleanliness, Tidiness and Facilities; 3. Friendliness and Patience of Employees in Serving the speed of service; 4. Employees who are helpful and friendly and considerate of customers; 5. Security and Comfort.
\end{abstract}

This is an open access article under the CC BY-SA license.

Corresponding Author:

Sunasih Mulianingsih

Institut Pemerintahan Dalam

Email: sunasihmulianingsih@gmail.com

\section{INTRODUCTION}

Many demands from society regarding the quality of public services. However, in reality, the services provided are a complaint about the community as complicated and tiring. [1]. Public service is something that a person or bureaucratic group does in providing assistance to the community to achieve certain goals. Effectiveness and efficiency are the goals of transferring affairs from being centralized to being regional affairs themselves so that authority rests on the regions.[2]. A service consisting of the implementation and reception of services (customers) becomes important and becomes a concern. The wider the scope of public services and services managed by the government covering all aspects of people's lives, it should be followed by good service quality.[3] Service quality is the most important thing for all agencies to achieve organizational goals and ensure the survival of the organization. Public services must pay attention to the needs of their customers.[4]. Customer needs will be met if the public service can provide services by meeting good service indicators. The expected public service is in accordance with the guidelines for the implementation of public services based on the Decree of the Minister for Empowerment of State Apparatus Number: 63/KEP/M.PAN/7/2003, concerning general guidelines for the implementation of public services such as service procedures, service requirements, service officer capabilities, speed services, fairness in getting services, the certainty of service costs, and certainty of service schedules, the government has consequences for improving services in the public service sector. [5]. Similar research that is relevant to this research is the work of Hartini Podungge. (2019).QUALITY OF E-KTP SERVICES IN THE DISTRICT OFFICE. The results of his research show that the service is based on SOP, the theory used is Zeithaml et al (in Pasolong 2007). The difference is that this study describes the one based on the Decree of the Minister of State Apparatus Empowerment Number:

Journal homepage: https://bajangjournal.com/index.php/IJSS 
63/KEP/M.PAN/7/2003. The results show that IT-based services must be balanced with HR competencies, and budget support as well as material readiness and e-service requirements. ID cards such as keeping are often late in supply from the Ministry of Home Affairs, so services are hampered. Thus, this study intends to identify and describe the EKTP service in the Cibeunying Kaler sub-district, Bandung city.

\section{RESEARCH METHOD}

Descriptive research method according to Nazir (1988:63) is a method in examining the status of a group of people, an object, a condition, a system of thought or a class of events in the present. The purpose of this descriptive research is to make a systematic, factual and accurate description, picture, or painting of the facts, characteristics and relationships between the phenomena being investigated. It can be said that descriptive research is research that seeks to describe a symptom, an event that is happening at the present time or an actual problem. The researcher uses a descriptive approach to provide a specific description of the Quality of E-KTP Services at the Cibeunying Kaler District Office, Bandung City.

The research method used in this research is qualitative. The qualitative approach according to [6] is a method with research that produces analytical procedures that do not use statistical analysis procedures or other quantification methods. According to Creswell J.W. qualitative approach is defined as a research process to understand human or social problems by creating a comprehensive and complex picture presented in words, reporting detailed views obtained from information sources, and carried out in a natural setting. Researchers use qualitative research methods because it is relevant to the research problems that will be examined by researchers related to the Quality of E-KTP Services at the Cibeunying Kaler District Office, Bandung City.

\section{Data Sources and Types}

Data source

Data for a study can be collected from a variety of sources. Data can also be sourced from within the organization called data sources or external data. External data sources are divided into primary data sources and secondary data sources.

\section{Data Type}

The type of data in this study uses a qualitative research method. According to (Sugiyono, 2018) is a research method based on the philosophy of post-positivism (phenomena and noumena), used to examine the condition of natural objects, as opposed to experiments where the researcher is the key instrument, data collection is done by triangulation (combined)., an analyst in general.

\section{Data collection technique}

The interview technique used in this study is a semi-structured interview. This type of interview is included in the indepth interview category, which is freer in its implementation compared to structured interviews. The purpose of this type of interview is to find problems more openly, where the parties invited to the interview are asked for their opinions and ideas [8].

\section{RESULTS AND DISCUSSION}

The following is a description of each dimension according to the research results and findings: (1) Dimensions of Service Speed, Results of Interviews with the Head of the Service Section said "The process in serving the community who will complete the E-KTP if it depends on the many pauses depending on the problem as well, if normally there is no problem at least serving 15 minutes if the file is submitted, now if the ID card itself is printed at the population service, it is approximately 2 weeks, one week to 2 weeks depending on the chip from the centre, the problem is still centralized, the problem of chips, if the chip is there, you can wait as Pak Jokowi said, it takes 1 hour so it can be done as long as the chips are actually available, the problem is that the availability of the chips is gradual from the centre at the Disduk, the ones that print out the e-KTP, we only facilitate the application for submitting an electronic ID card. the finish I guess that's a maximum of 2 weeks, at most 2 weeks now. The main obstacle is the availability of chips according to the needs provided by the Jakarta Ministry of Home Affairs, what the procedure is from, from the Department of Home Affairs submitting there maybe every week or every two weeks or until a month there, asking for pieces, not all at once a year, Bandung city doesn't ask for more. ask again, that's a maximum of 2 weeks sometimes a week depending on the availability of chips, more external factors if it's an e-ID card, the service is the problem that's beyond our control, if the pieces are printed on us, it's easy to just print them out according to the needs of the pieces, but you're invited The law is not like that because the law was printed by the Central government on the chip." (Interview 31 December 2018). 
International Journal of Social Science (IJSS)

Vol.1 No.2 August 2021, pp: 43-48

ISSN: 2798-3463 (Printed) | 2798-4079 (Online)

DOI: https://doi.org/10.53625/ijss.v1i2.135

Based on the results of research from the service section that the process that will complete the e-KTP if the requirements are complete include: RT/RW cover letter, photocopy of family card, photocopy of birth certificate, a personal certificate that has entered is complete, the service process can be completed quickly. but the sub-district office only facilitates further processing at the Population and Civil Registry Office. The sub-district also looks at the number or availability of chips that have been provided by the Center. Thus, the problem is that it depends on the availability of chips for ID cards. For services that can meet its citizens, the availability of tools/supporting resources is needed, [9].

(2) Dimensions of Cleanliness, Tidiness and Facilities. The following is the result of an interview with Heri, Head of the Service Section. "There is a service standard. It already uses service standards, we have to fill in what we are factual in the field, the evidence is what was uploaded, for example, how do you upload photos to the service system I later, the value appears, for example, must be 85 , for example, the point is that the standard of service is not just clothes. there are Standard Operating Procedures, there is a Vision and Mission, there is a service desk, there is air conditioning, TV is a standard of service, there are many indicators, so it must be fulfilled, including clothes, the problem is that if we change clothes, what personnel must make again, that's the problem because we can't really tell. In the end, it's uniform, because it's not a standard, the service attire has to be different from other services at the front office, there must be different rules, that's the standard of service according to the Public Service Act, if I'm not mistaken, it should be different, I think about facilities. everything is complete, especially in the city of Bandung, all sub-districts are now complete, just take a look The queuing machine is complete if it used to be manual, now it's rich in a bank in the sub-district." (Interview on 31 December 2018).

Based on these results, the dimensions of cleanliness, tidiness of staff and facilities at the Cibeunying Kaler District office are quite good and meet the Standard Operating Procedure (SOP), with the SOP that the District can improve the quality of its services to the community, there are many provisions that must be obeyed by employees in order to provide excellent service, meaning that in carrying out their duties there are work references that must be met at all times.[10]

(3) Dimensions of Employee Hospitality and Patience in Serving. Following are the results of an interview with the Secretary of the Camat, serving impatient customers: facing problems, we tend to have good communication that indeed every service carried out by the rules and SOPs that have been determined by providing a good understanding to the community, God willing, the community is indeed what it's called. If someone is fussy or something, but if there is an urgent interest in the community, for example getting faster service, we will see what the urgency is like, for example, he had to do this the last day, God willing, we will follow it too, so it's not too rigid as long as it maximizes service and speeds up Our service process is making efforts to maximize it to the community." (Interview, on January 10, 2019).

Based on the results of the interview above, employees at the Cibeunying Kaler District Office in Bandung City have been polite and friendly in providing services for making e-KTPs to the community, namely serving with a smile and then being friendly in service and speaking well to the community. This means that in serving the community must have a commitment to achieving organizational goals.[11].

(4) The dimensions of employees who are helpful and friendly and pay attention to customers, "If you need information, what do you need to complain about, if you don't feel lazy to come there, there must be a solution, there will be an explanation or if you really want to be clear, you have to check or take photos, check here, you can do that to improve service to the community, you don't always have to come here because there is technology, people can come here if there is a shortage of requirements, just take a photo via WA, we give a number to complain to ask anything, since there are stacks of queues not too out, if it used to be just Just asking for an e-KTP when it's over here, it's a waste of time, can you take a photo via WA, the receipt is done, it hasn't been checked yet, if it's just taken here, make the time effective for the community, "Cibeunying Kaler District Office, Bandung City has been able to adapt to the modern era this, everything is instant and not complicated, when looking for info The formation also does not always have to come directly to the District Office, but the office has also provided media to the public regarding anything that will be asked or whether or not the e-KTP has been made and others. (Interview, on January 10, 2019). Based on the results of interviews and observations, the sub-district office always adapts to the times and technology to improve the performance of e-KTP services [12]. However, communication between officers who serve and the community needs to be improved in line with advances in information technology so that they can continue to respond to the dynamics of community development [13].

(5) Safety and Comfort, the results of the interview with the head of Community Empowerment said "Surely there should be a TV so that people are not upset and of course the waiting room needs to be made as comfortable as possible

. Journal homepage: https://bajangjournal.com/index.php/IJSS 
starting from the existence of fish ponds and fountains in the sub-district in order to beautify and the people who see it cool". (Interview on January 10, 2019).

Facilities are also a determinant of the community feeling comfortable in service at the Cibeunying Kaler District Office. The provision of supporting facilities and other facilities such as television is also a fulfilment of the SOP which is the obligation of the sub-district to create quality services.[14].

\section{CONCLUSION}

Based on the results of the research and discussion, the researchers conclude (1) Dimensions of Service Speed, that the E-KTP service at the Cibeunying Kaler District Office is quite good, although there are still people who complain about the timeliness of completing the E-KTP. (2) Dimensions of Cleanliness, Neatness of Employees and Facilities, Quality of E-KTP Services at the Cibeunying Kaler District Office regarding Cleanliness, Neatness of Employees and Facilities have met the predetermined SOP. (3) Friendliness and Patience of Employees in serving, Following are the results of interviews with the head of the service section, the quality of E-KTP services at the Cibeunying Kaler District Office, Bandung City is good. Because the ability and skills of employees in providing services received a good response from the community, and employees were friendly and polite in serving. All indicators of the dimensions of Hospitality and Patience of employees in serving get a good response from the community. (4) Employees who are helpful and friendly and pay attention to customers, the quality of E-KTP services at the Cibeunying Kaler District Office, Bandung City regarding helpful and friendly employees and attention to This customer is good. Because in fact, employees have been able to provide sufficient satisfaction directly to the community, even though they have not fully provided satisfaction. (5) Security and comfort, the quality of E-KTP services at the Cibeunying Kaler District Office, Bandung City, the community already feel safe and comfortable in terms of adequate facilities and the friendly attitude of the employees makes the community feel happy and satisfied with the services provided.

Suggestions that researchers can put forward: (1) It is better if the e-KTP service at the Cibeunying Kaler District Office is currently maintained or even improved because the services provided have met the service quality indicators and are in accordance with the Decree of the Minister of State Apparatus Empowerment Number 63/KEP/ M.PAN/7/2003, concerning general guidelines for the implementation of public services. (2) It is necessary to improve the speed of service because employees provide unclear and uncertain information to the public regarding the processing time for the completion of the e-KTP.

\section{REFERENCES}

[1] G. O. D. dan L. W. K. Marshall E. Dimock, Public Administration. New York: The Ronald Press Company, 1960.

[2] E. Engkus, "Desentralisasi (Teori yang Baik dengan Praktek yang buruk)," JISPOJurnal Ilmu Soial dan Ilmu Polit., vol. 1(4), pp. 1-16, 2013.

[3] R. C. \& J. C. P. Chandler, The Public Administration Dictionary.Second Edition. Santa Barbara, CA: ABCCLIO Inc, 1988.

[4] N. Engkus, E., \& Ulfah, "Analisis Kinerja Pegawai Bagian Pelayanan Di PT. Pos Indonesia (Persero) Kantor Pos Subang," Minist. J. Birokrasi dan Pemerintah. Drh., vol. 1(1), pp. 39-61, 2019.

[5] Menpan RI, Keputusan Menteri Pendayagunaan Aparatur Negara Nomor: 63/KEP/M.PAN/7/2003,Menpan RI, 10 Juli. 2003.

[6] Lexy J. Moleong, Metode Penelitian Kualitatif (Cetakan 38). Bandung: Rosdakarya, 2018.

[7] Sugiyono, Metode Penelitian Kuantitatif, Kualitatif, dan R\&D. Bandung: Alfabeta, 2018.

[8] U. Silalahi, Metode Penelitian Sosial Kuantitatif. Bandung: Refika Aditama, 2017.

[9] E. Engkus, "The Influence Of Organizational Behavior On Work Ethics Employees In Bandung Regency Government," IASET, vol. 1(1), pp. 1-16, 2017.

[10] V. \& J. W. Gasperz, Manajemen Kualitas: Penerapan Konsep Konsep Kualitas Dalam Manajemen Bisnis Total. Jakarta: Kerjasama Yayasan Indonesia Emas Gramedia Pustaka Utama, 1994.

[11] E. Engkus, "Konsep Komitmen Organisasi Dalam Perspektif New Public Service," digiliibuinsgd.ac.id, vol. 1(16), pp. 1-27, 2015.

[12] E. Ishak, D., Maolani, D. Y., \& Engkus, "KONSEP KINERJA DALAM STUDI ORGANISASI PUBLIK," JISPO J. Ilmu Sos. dan Ilmu Polit., vol. 7(2), pp. 101-120, 2017. 
International Journal of Social Science (IJSS)

Vol.1 No.2 August 2021, pp: 43-48

ISSN: 2798-3463 (Printed) | 2798-4079 (Online)

DOI: https://doi.org/10.53625/ijjss.v1i2.135

[13] E. Engkus, "Implementasi Kebijakan Revitalisasi Pasar Tradisional Sarijadi Kota Bandung," Governansi, vol. 6(1), pp. 9-16, 2020.

[14] E. Engkus, Administrasi Kepegawaian Indonesia Pada Sektor Publik (Dalam Pendekatan Aparatur Sipil Negara). Bandung: Unpas Press, 2016. 
